\title{
Comparison of two phenotypical methods to segregate resistant and susceptible lambs to parasitic nematodes
}

\author{
Alvar Cruz-Tamayo ${ }^{\mathrm{a}, \mathrm{b}}$, Roberto González-Garduño ${ }^{\mathrm{c}}{ }^{*}$, Glafiro Torres-Hernández $^{\mathrm{a}}$, \\ Carlos M. Becerril-Pérez ${ }^{\mathrm{a}}$, Omar Hernández-Mendoa ${ }^{\mathrm{a}}$ Jacinto Efrén Ramírez-Bribiesca ${ }^{\mathrm{a}}$, \\ María E. López-Arellano ${ }^{d}$, Juan J. Vargas-Magaña ${ }^{b}$, Nadia F. Ojeda-Robertos ${ }^{\mathrm{e}}$
}

\begin{abstract}
The objective of this study was to compare two segregation methods to select resistant and susceptible female Pelibuey lambs infected naturally with gastrointestinal nematodes (GINs) in relation to their haematological and immunological response. For 6 months, faeces and blood samples were taken fortnightly from 40 grazing 5-month-old female lambs. The lambs were classified according to two methods using faecal egg count (FEC) as a phenotypical trait. In the first (reference) method (M3SE, $n=22)$, resistant (RES) lambs had FEC lower than the mean -3 standard errors, the susceptible (SUS) lambs levels higher than +3 standard errors $(\mathrm{n}=10)$ and the intermediate (INT) lambs $(\mathrm{n}=8)$ were categorised by having FECs between the two values. The second method (QUM) divided the population, using quartiles, into resistant (RES; 25\%), intermediate (INT; 50\%), and susceptible (SUS; 25\%) lambs. The agreement between both methods was estimated using the Kappa index. The packed cell volume (PCV), total plasma protein (TPP) and peripheral eosinophils (EOS) were determined for each group. Serum was used to evaluate the IgA levels. PCV and TPP values were higher $(P<0.01)$ in the RES lambs $(31.5 \pm 3.4$ and $6.16 \pm 0.5 \mathrm{~g} / \mathrm{dL}$ by QUM, respectively, and $31.5 \pm 3.9$ and $6.24 \pm 0.49 \mathrm{~g} / \mathrm{dL}$ by M3SE, respectively) than the SUS lambs ( $28.1 \pm 4.7$ and $5.94 \pm 0.5 \mathrm{~g} / \mathrm{d}$, respectively, by both methods). The EOS and IgA values increased with age. M3SE and QUM were in moderate agreement $($ Kappa $=0.43)$. We concluded that the two segregation methods allowed for the identification of the same female SUS lambs, but a greater number of animals were categorised phenotypically as resistant using the M3SE method. PCV and TPP can help to identify phenotypically resistant animals.

Key words: eosinophils, selection, $\operatorname{Ig} \mathrm{A}$, plasma protein.
\end{abstract}

\section{INTRODUCTION}

Gastrointestinal nematodes (GINs) are responsible for the deterioration in sheep health, especially in tropical areas, where climatic conditions favour their development and propagation throughout the year. GINs infections limit the productivity of sheep, causing economic losses due to low weight gain and increased mortality in the most susceptible animals. Among parasitic nematode infections, the most important is that caused by Haemonchus contortus because, in addition to its high prevalence and pathogenicity, it is a hematophagous species, making it a risk for animal health (Mavrot et al 2015).

Nematode infections have been mainly controlled using anthelmintics. The use of these products has helped to control the effects of parasitism, but their frequent use to eliminate susceptible nematodes has led to the selection

Received: 08.05.2019.

Accepted: 22.10.2019

${ }^{a}$ Colegio de Postgraduados, Campus Montecillo, Montecillo, Estado de México, México.

${ }^{\mathrm{b} E s c u e l a ~ S u p e r i o r ~ d e ~ C i e n c i a s ~ A g r o p e c u a r i a s, ~ U n i v e r s i d a d ~ A u t o ́ n o m a ~}$ de Campeche, Escárcega, Campeche, México.

'Unidad Regional Universitaria Suroeste, Universidad Autónoma Chapingo, Tabasco, México.

${ }^{\mathrm{d} C e n t r o ~ N a c i o n a l ~ d e ~ I n v e s t i g a c i o ́ n ~ D i s c i p l i n a r i a ~ e n ~ S a l u d ~ A n i m a l ~ e ~}$ Inocuidad, INIFAP, Morelos, México.

eDivisión Académica de Ciencias Agropecuarias, Universidad Juárez Autónoma de Tabasco, Tabasco, México.

*Corresponding author: R González-Garduño, robgardu@ @otmail.com of populations with anthelmintic resistance (AR). For this reason, these drugs have lost their effectiveness against several GINs species (Rose et al 2015). Alternative methods to control the effects of GINs, and combinations of these methods, have been widely used to avoid AR problems (McMahon et al 2013).

The host resistance is the ability to control the infection of endo-parasitic stages, contrary to susceptible ones that allow the infection with acute clinical signs. Parasitic infections with GINs consider the faecal egg count (FEC) as the main indicator to identify phenotypically resistant hosts. Selecting for increased resistance leads to decreased FEC resulting from ever-decreasing pasture contamination and hence decreased infectious challenge (Bishop 2012). The search for natural genetic resistance in sheep as the main objective implies the selection of several generations of sheep because genetic resistance against GINs is a moderately heritable characteristic $\left(h^{2}=0.11\right.$ to 0.40 , Gauly and Erhardt 2001). To demonstrate this genetic resistance, phenotypic, histological, immunological and molecular indicators have been studied (Sweeney et al 2016). Despite its limitations, FEC is the phenotypic indicator that is most frequently used to assess the level of parasitic infection because is an estimator of parasitic burden (Morris et al 2000). However, identifying the most heavily infected individuals requires several samples due to variability in FEC. For this reason, several pathophysiological indicators have since been developed to indicate the presence and intensity of a GINs infection, such as the packed cell volume (PCV) to indicate anaemia. Similarly, the dag score and body condition has also been used to 
evaluate the health deterioration caused by nematode infection (Bentounsi et al 2012).

To detect animals with resistance, several segregation methods have been used. One of these is the arithmetic mean of FEC along with the standard error (Morteo-Gómez et al 2004). The other method uses practical rules and categorises animals as resistant when they have a FEC $<1000$ eggs per gram of faeces (EPG), intermediate when the FEC is between 1000 and 2500 EPG and susceptible if it is >2500 EPG (Fakae et al 2004). In recent years, hair sheep have been segregated using the quartile method (Palomo-Couoh et al 2016, Zaragoza-Vera et al 2019). Others studied indicators include PCV, total plasma protein (TPP), pepsinogen, blood cell count and immunoglobulin, mainly $\operatorname{IgA}$ and $\operatorname{IgE}$. These have been explored for the effective identification of natural resistance to GINs in sheep (Preston et al 2014, Zaros et al 2014).

The main host defence mechanism against GINs is acquired immunity, which develops over time in response to reinfection and depends on age, nutritional status and genotype (McRae et al 2015). A current challenge for sheep breeders is allowing sufficient GINs exposure to develop immunity without impairing growth, and hence herd productivity, and maintaining anthelmintic efficacy on farms (McMahon et al 2013). Due to this situation, the proposed hypothesis was that the lambs will express acquired resistance against GINs according to their segregation, which implies that resistant female lambs will have more eosinophils and better haematological values than susceptible sheep. The objective of this study was to compare two segregation methods to select resistant and susceptible female Pelibuey lambs naturally infected with GINs in relation to their haematological and immunological response.

\section{MATERIAL AND METHODS}

\section{STUDY AREA LOCATION}

The study was conducted at the Centre for Training and Reproduction of Small Species (CECAREM) in Tabasco, México, located in Villahermosa $\left(17^{\circ} 92^{\prime} \mathrm{N}, 9^{\circ} 00^{\prime} \mathrm{W}\right)$. The climate of the region is hot humid with rain throughout the year ${ }^{1}$. The mean temperature is $27.1^{\circ} \mathrm{C}$ and annual rainfall is $1958 \mathrm{~mm}$ (figure 1).

\section{ANIMAL MANAGEMENT}

From a group of 300 contemporary Pelibuey lambs born in a controlled mating, 40 lambs aged 5 months with age differences not exceeding 15 days were selected.

1 SMN, Servicio Meteorológico Nacional. 2019. Normales Climatológicas del estado de Tabasco. https://smn.cna.gob.mx/es/ informacion-climatologica-por-estado?estado=tab. Consulted 11.03.2019.

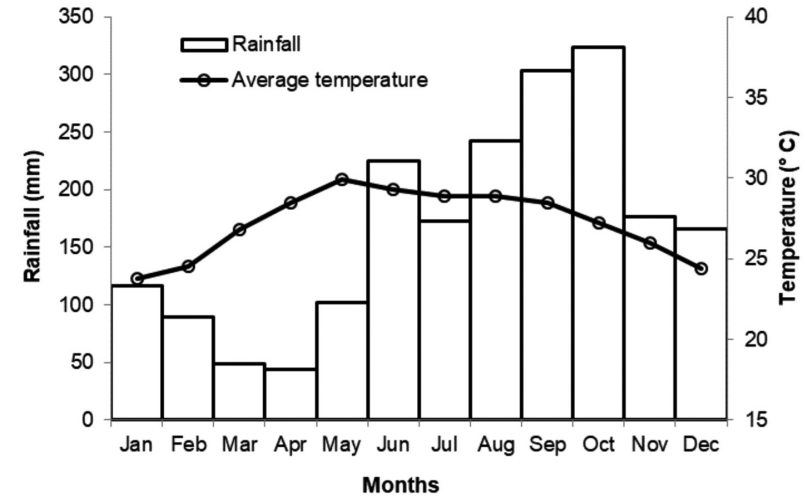

Figure 1. Mean monthly temperature (lines) and monthly distribution of rainfall (columns) throughout the year in Villahermosa, Tabasco, México. Obtained from the National Meteorological Service. Climatological norms of the Tabasco state.

https://smn.cna.gob.mx/es/informacion-climatologica-por-estado? estado=tab

Additionally, all selected lambs showed similar body condition and were kept in a group that received similar food and sanitary handling. During the trial, all the lambs grazed on the same paddocks of Star grass pasture (Cynodon nlemfuensis) and were naturally infected with GINs for 6 months from May to October.

The lambs were protected in galleys. They were supplemented with $200 \mathrm{~g}$ of food (14\% crude protein) and received water ad libitum. The procedures were performed following the Mexican Official Standard guideline 051ZOO-1995 and the Mexican Official Standard of technical specifications for production, care and use of experimental animals.

\section{PARASITOLOGICAL AND IMMUNOLOGICAL METHODS}

The group of female lambs remained in-house from birth to 5 months old, at which time the natural infection began during grazing. Blood and faecal samples were collected every 14 days over the 6 months from April to October. The faecal samples were collected directly from the rectum and the FEC was determined according to the McMaster method (Cringoli et al 2004) with a sensitivity of 50 EPG. Also, faecal cultures were processed to collect infective larvae (L3) at the beginning, middle and end of the study period and morphological identification was made using the practical laboratory guide of van Wyk and Mayhew (2013). Blood samples were obtained from the jugular vein into EDTA tubes and other samples were collected in tubes with a coagulation accelerator (Vacutainer, Becton Dickinson, New York, USA). PCV was determined by the microhaematocrit technique, and peripheral eosinophils (EOS) were counted in a Neubauer chamber after staining the cells with Carpentier solution (Dawkins et al 1989). TPP was quantified in a refractometer (Atago, Japan). Serum samples were centrifuged at $2000 \mathrm{~g}$, then stored at $-20^{\circ} \mathrm{C}$ 
until use. An indirect ELISA was used to determine the IgA level (\% OD with respect to positive control), using Haemonchus contortus and Trichostrongylus colubriformis crude extract antigen, according to the technique of González-Garduño et al (2017).

\section{CRITERIA FOR THE SELECTION OF RESISTANT AND SUSCEPTIBLE INFECTED HOSTS}

The arithmetic mean FEC of the whole trial, which consisted of 11 biweekly samples, was used to classify the host response against GINs as resistant (RES), susceptible (SUS) or intermediate (INT), using two methods. In the first, the lambs were classified using the mean \pm 3 standard errors (M3SE) as follows: RES female lambs were chosen as those with FECs less than the mean - 3SE; SUS lambs were those with FECs greater than the mean + 3SE; the INT group was defined by FECs between the two ranges (Morteo-Gómez et al 2004).

In the second method, the quartile method (QUM), as previously described by Palomo-Couoh et al (2016), was used. Briefly, the lambs were divided as follows: the first quartile (Q1) of infected lambs with low FEC were identified as RES hosts (25\%); the lambs in the highest FEC and third quartile (Q3) were identified as SUS (25\%); and a third group, considered INT, had a FEC between Q1 and Q3 and represented 50\% of the total population.

\section{STATISTICAL ANALYSIS}

To compare the two methods, the Kappa index (Landis and Koch 1977) was calculated with the formula Po - Pe/ $(1-\mathrm{Pe})$. Where Po $=$ total proportion of concordance observed and $\mathrm{Pe}=$ expected random proportion. The concordance value (Youden's J), sensitivity, specificity, predicted positive and negative values, the proportion of false positives and false negatives, and the accuracy were calculated according to Palomo-Couoh et al (2016) relative to an assumed reference method (M3SE). To perform the validity test, the data were grouped in $2 \times 2$ contingency tables, considering as reference the method of M3SE, because the mean values together with the standard deviation are part of the theory of the selection of animals used to calculate the genetic progress of phenotypic characteristics (Morris et al 2000, McRae et al 2014).

To compare the response of each segregated group (RES, INT and SUS) a multivariate linear mixed-effect regression model was used under a design of repeated measures over time, by which different covariance structures were tested for each study variable. The autoregressive structure (AR1) was selected and adjusted to each model by presenting lower $\mathrm{AIC}$ and BIC values. The analysis was performed with the MIXED procedure of SAS software (SAS, 2004). Two segregation methods were considered (M3SE and QUM) and one statistical analysis was performed per variable in each method (10 runs in total). Untransformed FEC data and other response variables (PCV, TPP, EOS and IgA) were analysed (Peña-Espinoza et al 2016) following the statistical model:

$$
\mathrm{Y}_{\mathrm{ijkl}}=\mu+\rho_{\mathrm{i}}+\tau_{\mathrm{j}}+\rho^{*} \tau_{\mathrm{ij}}+\zeta(\rho)_{\mathrm{ik}}+\varepsilon_{\mathrm{ijkl}}
$$

where $\mathrm{Y}_{\mathrm{ijkl}}=$ response variable (FEC, PCV, TPP, EOS, $\operatorname{IgA}) ; \mu=$ general mean; $\rho_{\mathrm{i}}=$ fixed effect of the treatment ( $i=$ RES, INT, SUS); $\tau_{j}=$ fixed effect of time $(j=1,2$, $3 . .11$ samplings); $\rho * \tau_{\mathrm{ij}}=$ joint effect of treatment and time; $\zeta(\rho)_{\text {ik }}=$ random effect of the animal nested in each treatment; and $\varepsilon_{\mathrm{ijkl}}=$ experimental error. Comparisons of RES, INT and SUS and differences in time of sampling were observed with Tukey's tests (SAS 2004). Pearson correlations were calculated to determine the relationship between the response variables (FEC, PCV, TPP, IgA) in each of the segregated groups (RES and SUS) per method. Spearman correlations were made for age and countable variables. With regard to the interaction between time and treatment (dynamics), the study focused only on the divergent performance of RES and SUS groups.

\section{RESULTS}

\section{CLASSIFICATION OF LAMBS ACCORDING TO NEMATODE INFECTION}

Table 1 shows the parameters FEC, TPP, TCV and EOS according to the classification of the female Pelibuey lambs. In the first parasitic classification method (M3SE), 22 infected lambs were identified as RES (55\%), 8 as INT (20\%) and 10 as SUS (25\%). Using the second method (QUM), 10 infected lambs (25\%) were identified as RES, $20(50 \%)$ as INT and 10 as SUS (25\%). The SUS lambs corresponded to the same animals under the two methods, so the study variables were similar. The arithmetic mean of FEC during the study period for the SUS group was higher (672 EPG) than that of the RES (171 EPG and 288 EPG) and INT groups (39 EPG and $67 \mathrm{EPG}$ ) from QUM and M3SE methods, respectively $(P<0.05)$. The mean FEC in the RES group was similar in the two methods. For TPP and PCV analysis, there was an increased response in the resistant group, and the lowest TPP and PCV values were obtained for the susceptible group $(P<0.05)$ in both methods.

The Kappa index between the two methods was moderate (0.43). When comparing the QUM with the M3SE as a standard method, it was observed that QUM showed low sensitivity and a low percentage of negative predictive values, where only 10 of the 22 resistant lambs were detected, so the accuracy was $70 \%$ and the Youden index was 0.5 (table 2).

\section{DYNAMICS OF FAECAL EGG COUNT}

The same lambs were categorised as SUS lambs by both QUM and M3SE methods, so the performance was 
Table 1. Arithmetic mean of faecal egg count, packed cell volume and total plasma protein throughout the study period in female Pelibuey lambs classified as resistant, intermediate and susceptible according to segregation method.

\begin{tabular}{|c|c|c|c|c|c|c|c|c|c|}
\hline \multirow{3}{*}{ Variable and method } & \multicolumn{9}{|c|}{ Female lamb phenotype classification } \\
\hline & \multicolumn{3}{|c|}{ Resistant } & \multicolumn{3}{|c|}{ Intermediate } & \multicolumn{3}{|c|}{ Susceptible } \\
\hline & $\mathrm{N}$ & Mean & SD & $\mathrm{N}$ & Mean & SD & $\mathrm{N}$ & Mean & SD \\
\hline \multicolumn{10}{|c|}{ Faecal egg count (EPG) } \\
\hline Method 1. M3SE & 22 & $67 \pm$ & $123^{\mathrm{a}}$ & 8 & $288 \pm$ & $532^{\mathrm{b}}$ & 10 & $672 \pm$ & $1068^{c}$ \\
\hline Method 2. QUM & 10 & $39 \pm$ & $65^{\mathrm{a}}$ & 20 & $171 \pm$ & $372^{\mathrm{b}}$ & 10 & $672 \pm$ & $1068^{c}$ \\
\hline \multicolumn{10}{|l|}{ Packed cell volume $(\%)$} \\
\hline Method 1. M3SE & 22 & $31.5 \pm$ & $3.9^{\mathrm{a}}$ & 8 & $32.3 \pm$ & $3.7^{\mathrm{a}}$ & 10 & $28.1 \pm$ & $4.7^{b}$ \\
\hline Method 2. QUM & 10 & $31.5 \pm$ & $3.4^{\mathrm{a}}$ & 20 & $31.9 \pm$ & $4.0^{\mathrm{a}}$ & 10 & $28.1 \pm$ & $4.7^{\mathrm{b}}$ \\
\hline \multicolumn{10}{|c|}{ Total plasma protein $(\mathrm{g} / \mathrm{dL})$} \\
\hline Method 1. M3SE & 22 & $6.24 \pm$ & $0.49^{\mathrm{a}}$ & 8 & $6.02 \pm$ & $0.44^{\mathrm{b}}$ & 10 & $5.94 \pm$ & $0.50^{\mathrm{b}}$ \\
\hline Method 2. QUM & 10 & $6.16 \pm$ & $0.50^{\mathrm{a}}$ & 20 & $6.19 \pm$ & $0.48^{\mathrm{a}}$ & 10 & $5.94 \pm$ & $0.50^{\mathrm{b}}$ \\
\hline \multicolumn{10}{|c|}{ Peripheral eosinophils (cells $/ \mu \mathrm{L}$ ) } \\
\hline Method 1. M3SE & 22 & $460 \pm$ & $633^{\mathrm{a}}$ & 8 & $407 \pm$ & $463^{\mathrm{a}}$ & 10 & $363 \pm$ & $380^{\mathrm{a}}$ \\
\hline Method 2. QUM & 10 & $377 \pm$ & $376^{\mathrm{a}}$ & 20 & $481 \pm$ & $673^{\mathrm{a}}$ & 10 & $363 \pm$ & $380^{\mathrm{a}}$ \\
\hline
\end{tabular}

EPG: Eggs per gram of faeces. QUM: Quartile method. M3SE: Means-3 standard error method. Different lowercase letters in the same row indicate significant differences $(P<0.05)$. SD, Standard deviation. SE, Standard error.

Table 2. Evaluation of the concordance between two segregation methods to detect resistant Pelibuey female lambs against gastrointestinal nematodes.

\begin{tabular}{|c|c|c|c|c|}
\hline \multirow{3}{*}{ Item } & \multicolumn{4}{|c|}{ Segregation method } \\
\hline & \multicolumn{2}{|c|}{ Mean-3 Standard Error } & \multicolumn{2}{|c|}{ Quartile } \\
\hline & Value & CI $95 \%$ & Value & CI $95 \%$ \\
\hline Sensitivity (\%) & 100.0 & $85.1-100.0$ & 45.5 & $26.9-65.3$ \\
\hline Specificity (\%) & 100.0 & $82.4-100.0$ & 100.0 & $82.4-100.0$ \\
\hline Positive predictive value (\%) & 100.0 & $85.1-100$ & 100.0 & $72.2-100.0$ \\
\hline Negative predictive value (\%) & 100.0 & $82.4-100$ & 60.0 & $42.3-75.4$ \\
\hline False positives proportion $(\%)$ & 0.0 & $0.0-17.6$ & 0.0 & $0.0-17.6$ \\
\hline False negative proportion (\%) & 0.0 & $0.0-14.9$ & 54.5 & $34.7-73.1$ \\
\hline Accuracy $(\%)$ & 100.0 & $91.2-100$ & 70.0 & $54.6-81.9$ \\
\hline Youden $\mathrm{J}$ index (\%) & 1.0 & & 0.5 & \\
\hline
\end{tabular}

similar. However, for RES lambs, there were a greater number of animals categorised by M3SE $(n=22)$, while only 10 lambs were selected by QUM. An increase in FEC was shown from August to October, especially in SUS female lambs (figure 2), which was attributable to the increase in rainfall during the months of August to October (figure 1). The nematode species recovered from the faecal cultures at the beginning of the experiment were Haemonchus spp. (77\%), Trichostrongylus spp. (16\%) and Oesophagostomum spp. (7\%). These species remained in similar proportions until the end of the study $(65.64 \%$, $25.04 \%$ and $9.32 \%$, respectively).
DYNAMICS OF PACKED CELL VOLUME AND TOTAL PLASMA PROTEIN

The PCV percentage in RES lambs showed significant differences $(P<0.01)$ with respect to SUS lambs (table 1$)$. From April to June, the PCV value remained normal. However, after the rainy season at the end of July, the FEC increased and the PCV percentage decreased (figure 3) due to the presence of blood-feeding nematodes such as $H$. contortus. In August, the PCV increased when the FEC decreased slightly, as suggested by the correlation coefficient (CORR; $r=-0.23$ ). The lowest PCV value 


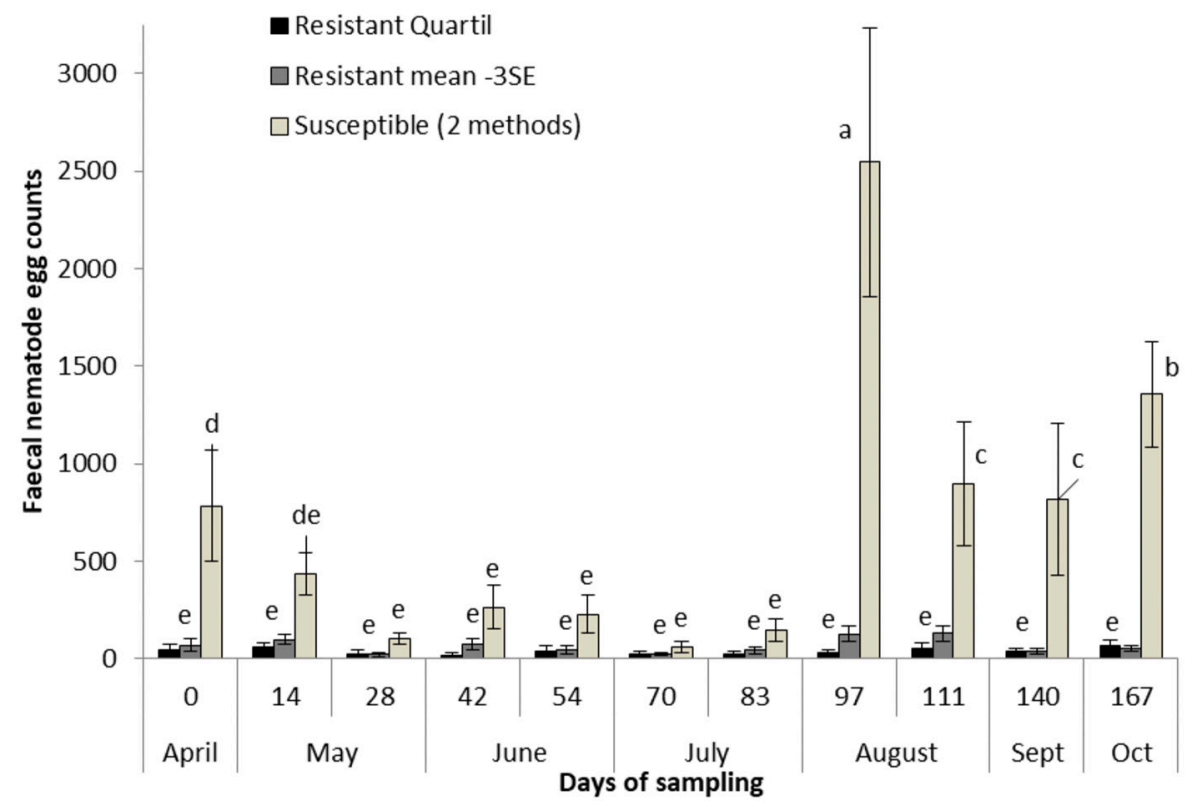

Figure 2. Divergent behaviour of nematode eggs per gram of faeces determined in resistant lambs ( $\mathrm{n}=10$ in quartile method, $\mathrm{n}=22$ in mean - 3SE method) and susceptible lambs $(n=10$; both methods were similar) in Pelibuey breed by month and sampling day. The bars represent the $\mathrm{SE}$ in each group. The different letters of each group represent statistical differences $(P<0.01)$.

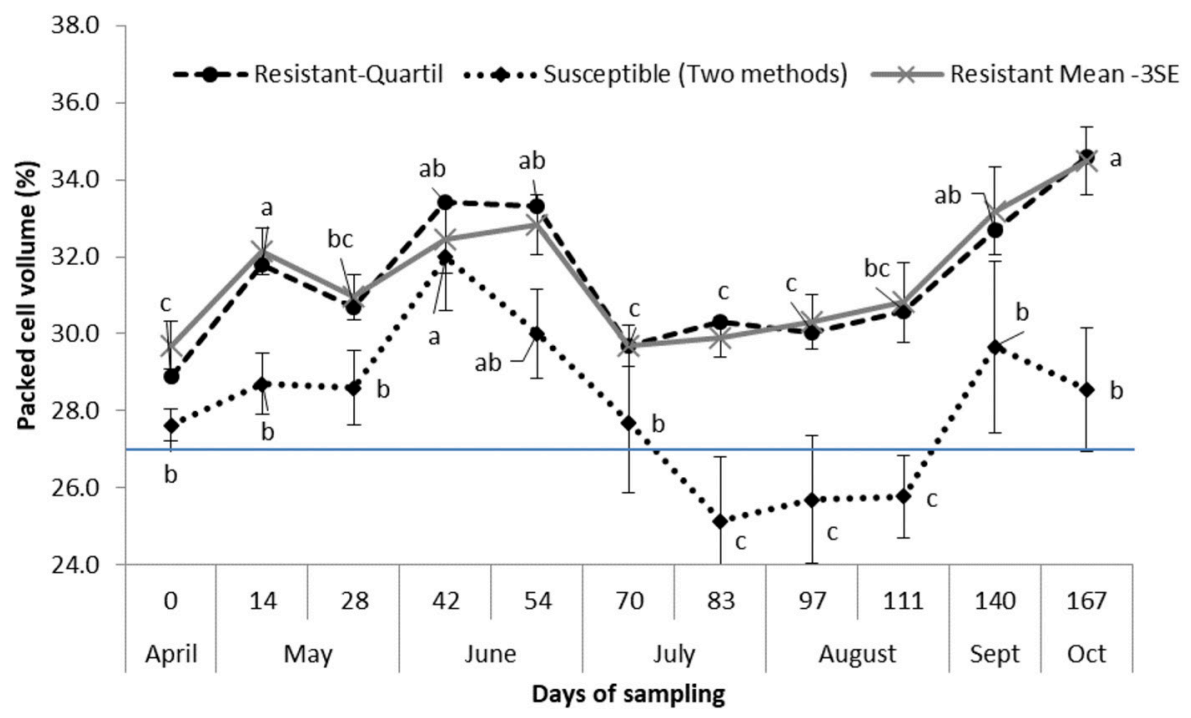

Figure 3. Divergent behaviour of PCV determined in resistant lambs ( $n=10$ in quartile method, $n=22$ in mean - 3SE method) and susceptible lambs $(n=10$; both methods were similar) in Pelibuey breed by month and sampling day. The bars represent the SE in each group. The different letters of each group represent statistical differences $(P<0.01)$. The solid line represents the threshold physiological level.

(26\%) was observed between days 83 and 97 in SUS lambs.

For the TPP analysis, there was a significant reduction $(P<0.01)$ between days 28 and 42 and a tendency towards a reduction in the last three samplings for RES lambs. The SUS lambs had values below $6 \mathrm{~g} / \mathrm{dL}$, the physiological threshold, in 54\% of the samples (figure 4). Also, TPP values decreased when the FEC increased, which was shown by the CORR (table 3 ).

\section{PERIPHERAL EOSINOPHIL DYNAMICS}

In this analysis, there were no differences in EOS counts between the RES and SUS lambs segregated according to either method. There was also a progressively increased number of eosinophils as female lambs grew older. Figure 5 shows the change in EOS count with time. The CORR between age and the number of eosinophils was high $(\rho=0.43)$, and remained similar in both RES and SUS animals regardless of the segregation method. 


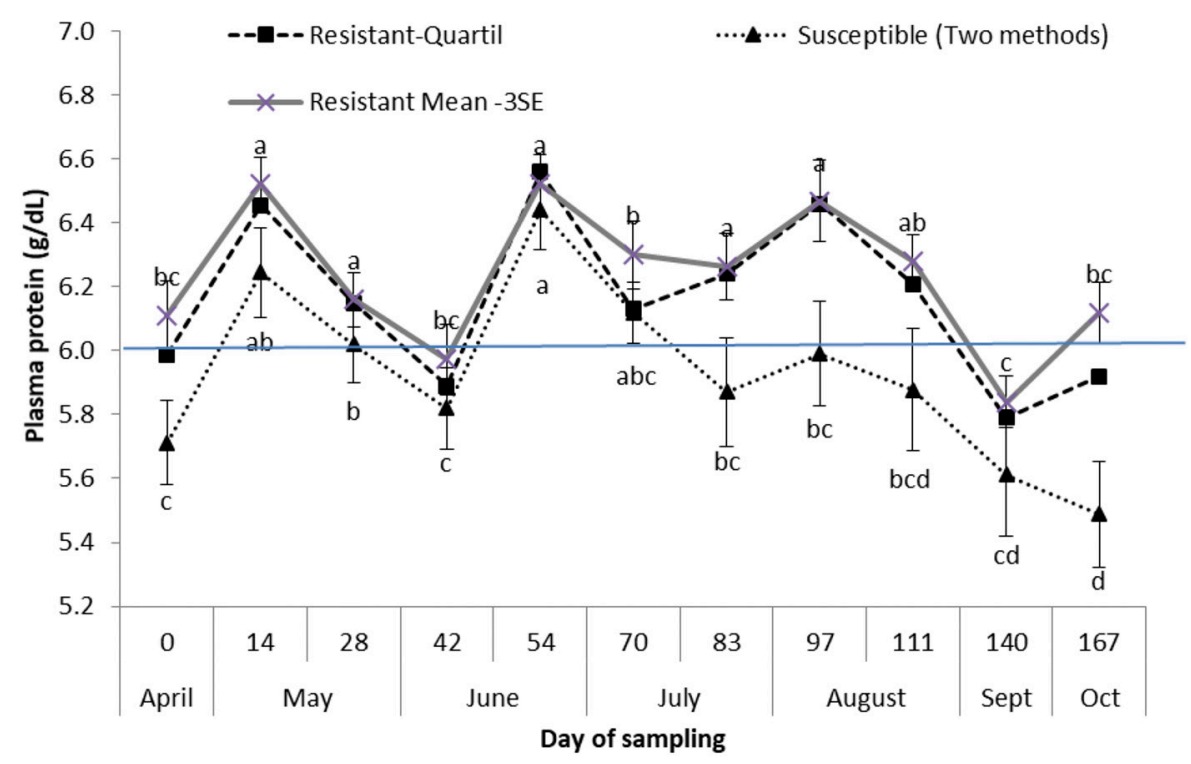

Figure 4. Divergent behaviour of TPP determined in resistant lambs ( $n=10$ in quartile method, $n=22$ in mean - 3SE method) and susceptible lambs ( $\mathrm{n}=10$; both methods were similar) in Pelibuey breed by month and sampling day. The bars represent the SE in each group. The different letters of each group represent statistical differences $(P<0.01)$. The solid line represents the threshold physiological level.

Table 3. Correlation coefficients between the studied variables in Pelibuey female lambs classified as resistant and susceptible according to segregation methods.

\begin{tabular}{|c|c|c|c|}
\hline \multirow{2}{*}{ Variable } & \multicolumn{2}{|c|}{ Resistant } & \multirow{2}{*}{$\begin{array}{c}\text { Susceptible } \\
\text { Two methods }\end{array}$} \\
\hline & Method -3 SE & Quartile & \\
\hline \multicolumn{4}{|l|}{ Age (days) } \\
\hline Faecal egg counts (EPG) & $0.01^{\mathrm{ns}}$ & $0.06^{\mathrm{ns}}$ & $0.29^{* *}$ \\
\hline Packed cell volume (\%) & $0.17^{* *}$ & $0.21^{*}$ & $-0.09^{\mathrm{ns}}$ \\
\hline Total plasma protein $(\mathrm{g} / \mathrm{dL})$ & $-0.12^{\mathrm{ns}}$ & $-0.15^{\mathrm{ns}}$ & $-0.27^{* *}$ \\
\hline Peripheral eosinophils (cells $/ \mu \mathrm{L}$ ) & $0.47^{* *}$ & $0.45^{* *}$ & $0.44^{* *}$ \\
\hline IgA*-H. contortus antigen & $0.47^{* *}$ & $0.47^{* *}$ & $0.50^{* *}$ \\
\hline IgA*-T.colubriformis antigen & $0.44^{* *}$ & $0.34^{* *}$ & $0.42^{* *}$ \\
\hline \multicolumn{4}{|l|}{$\operatorname{PCV}(\%)$} \\
\hline Total plasma protein $(\mathrm{g} / \mathrm{dL})$ & $0.147^{*}$ & $-0.15^{\mathrm{ns}}$ & $0.12^{\text {ns }}$ \\
\hline Peripheral eosinophils (cells/ $\mu \mathrm{L}$ ) & $0.30^{* *}$ & $0.45^{* *}$ & $0.13^{\mathrm{ns}}$ \\
\hline IgA*-H. contortus antigen & $0.35^{* *}$ & $0.47^{* *}$ & $0.26^{*}$ \\
\hline IgA*-T.colubriformis antigen & $0.32^{* *}$ & $0.34^{* *}$ & $0.24^{\mathrm{ns}}$ \\
\hline \multicolumn{4}{|l|}{ FEC } \\
\hline Packed cell volume (\%) & $-0.04^{\mathrm{ns}}$ & $0.03^{\text {ns }}$ & $-0.22^{*}$ \\
\hline Total plasma protein $(\mathrm{g} / \mathrm{dL})$ & $-0.02^{\mathrm{ns}}$ & $-0.02^{\mathrm{ns}}$ & $-0.26^{* *}$ \\
\hline \multicolumn{4}{|l|}{ TPP (g/dL) } \\
\hline Peripheral eosinophils (cells $/ \mu \mathrm{L}$ ) & $-0.06^{\mathrm{ns}}$ & $-0.10^{\mathrm{ns}}$ & $-0.23^{*}$ \\
\hline IgA*-T.colubriformis antigen & $0.19^{*}$ & $0.22^{\mathrm{ns}}$ & $-0.04^{\mathrm{ns}}$ \\
\hline \multicolumn{4}{|l|}{ IgA $*-H$. contortus antigen } \\
\hline IgA*-T.colubriformis antigen & $0.88^{* *}$ & $0.91^{* *}$ & $0.95^{* *}$ \\
\hline
\end{tabular}

IgA*: \% OD respect to the positive control. FEC: Faecal egg count. TPP: Total plasma protein. PCV: Packed cell volume. ** Highly significant differences $(P<0.01)$. * Significant differences $(P<0.05)$. ns $=$ Not significant differences $(P>0.05)$. 


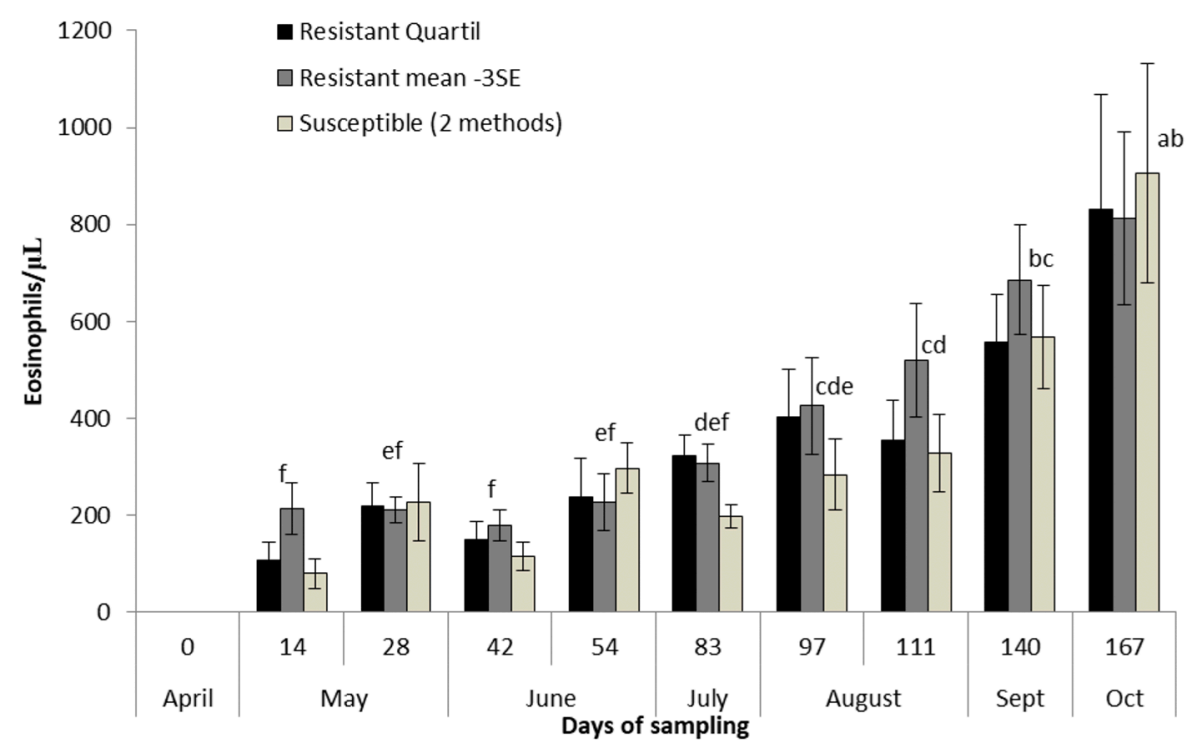

Figure 5. Simple effect of peripheral eosinophil counts in contemporary female Pelibuey lambs $(n=40)$ by sampled day and age. The bars represent the SE in each group and different letters represent significant statistical differences $(P<0.01)$. The different letters by the arithmetic mean for all groups represent statistical differences $(P<0.01)$.

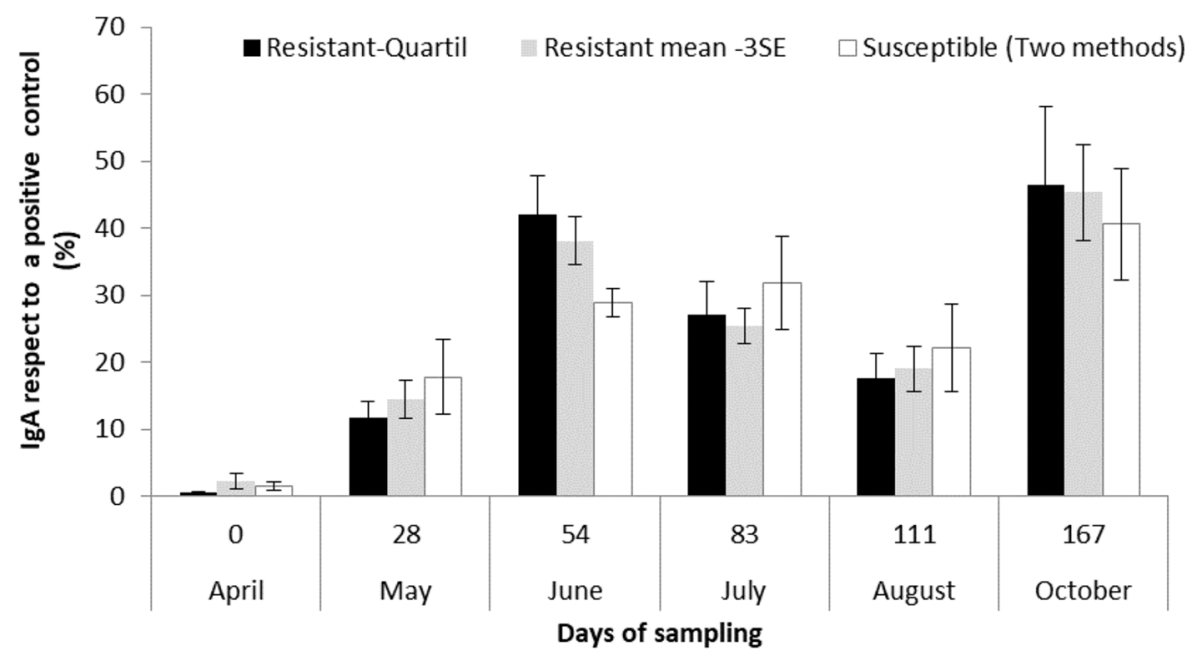

Figure 6. IgA levels respect to a positive standard control using $H$. contortus somatic antigen in resistant lambs $(\mathrm{n}=10$ in quartile method, $\mathrm{n}=22$ in mean - 3SE method) and susceptible lambs $(\mathrm{n}=10$; both methods were similar) in Pelibuey breed by month and sampling day. The bars represent the SE in each group. A similar response was seen with T. colubriformis.

\section{DYNAMICS OF IMMUNOGLOBULIN A}

The female lambs showed low levels of serum IgA (2\% with respect to the control) from initial sampling (day 0), increasing gradually with age $(P<0.05)$. Lambs showed increased levels of IgA after 7 months of age $(50 \%$ with respect to the positive control); these results show that IgA tended to increase with animal age, in association with FEC (figure 6); this was also seen in the CORR values, which were high ( $\rho=0.44$ to 0.47 ). The IgA response in RES lambs was similar to that in SUS lambs. Also, the immune response with $\operatorname{IgA}$ was similar between the two species of nematodes used (H. contortus and T. colubriformis).

\section{CORRELATION COEFFICIENTS}

The FEC, PCV, number of eosinophils and IgA levels increased with age $(P<0.05)$. TPP had a negative coefficient; therefore, as age increased, the TPP values decreased $(\rho=-0.14, P<0.01)$. In the RES lambs, the FEC had no 
significant correlation $(P>0.05)$ with PCV or TPP, whereas in the SUS lambs there was no relationship of PCV with TPP, eosinophils or IgA levels (table 3). Other important correlations occurred between FEC and TPP, with negative values $(r=-0.23)$ in SUS lambs. The correlation coefficients between the crude worm antigen of $H$. contortus and $T$. colubriformis were very high $(\mathrm{r}=0.90)$.

\section{DISCUSSION}

\section{FAECAL EGG COUNT}

In the grazing lambs, the ingestion of infective larvae will tend to homogenise over longer periods (Stear et al 2007). Under this scenario, the RES, SUS and INT lambs would have the same chance of becoming infected and the difference between the methods would be the choice of resistant animals. The use of the QUM and M3SE allowed for the classification of the same SUS lambs. However, in RES lambs, M3SE allowed for the selection of 22 individuals, whereas with QUM only 10 were categorised as RES. In our study, in $70 \%$ of samplings ( 7 out of 11 samplings), more than $25 \%$ of lambs showed 0 EPG, and the complication of QUM was to detect RES lambs when more than $25 \%$ showed resistance, as occurred in the flock. The objective of any segregation method is to select lambs for phenotypical resistance or tolerance to GIN infection that will result in a reduced reliance on anthelmintics to control parasitic nematodes, with the associated economic advantages (Cloete et al 2007). This is especially important when many animals exhibit resistance in at least at some of their physiological stages, as is the case during female lamb growth. This situation requires either many samples to detect differences between the RES animals, or the inclusion of another variable to select lambs with GIN resistance. For this reason, M3SE was considered the method of reference.

The M3SE method allowed to select at least all lambs with 0 EPG, therefore, the lambs not selected by the QUM method were considered as false negatives. For this reason, QUM showed low sensitivity.

When selecting for resistance to GINs, it is important to consider that FEC has a very small heritability ( 0.16 to 0.22; Morris et al 2005). Also, environmental conditions (feeding, facilities, pasture management), together with animal variables (such as age, development of immunity and physiological stage; González-Garduño et al 2014) and parasite variables (species of nematode, length of survival of parasite in the host, arrested development of infections, etc), lead to differences in the faecal egg output per month, as indicated in other studies (Amarante et al 2009). The classified groups showed significant differences $(P<0.05)$ between RES and SUS lambs in both the FEC and PCV. The RES lambs showed lower FEC and higher PCV than SUS lambs, as indicated in another study with Pelibuey ewes during lactation (Palomo-Couoh et al 2016).
PACKED CELL VOLUME AND TOTAL PLASMA PROTEIN

PCV and TPP are used to evaluate the degree of resistance or resilience to GIN infections, mainly when $H$. contortus is the most prevalent GIN. In this study, the values of both parameters remained within the physiological threshold for sheep (PCV from 27 to $45 \%$ and TPP from 6 to $7.5 \mathrm{~g} / \mathrm{dL}$; Byers and Kramer, 2010). The PCV values were lower than the physiological threshold during the rainy months (July and August), in response to an increase in the FEC associated with the high prevalence of $H$. contortus. This situation has been widely reported, and several studies indicate a very high negative correlation coefficient between FEC and PCV ( $\mathrm{r}=-0.7)$ when this nematode is present (Amarante et al 2009, Emery et al 2016). However, the correlation coefficient found in our study was only -0.23 . TPP also had a similar magnitude of correlation with FEC $(\mathrm{r}=-0.20)$, so both variables can be used as indicators of resistance to GIN, since the values were higher in resistant lambs. As indicated in another study, TPP can be effective in selecting animals with greater resistance to GINs (Zaros et al 2014). The slightly diminished TPP values in susceptible lambs could be an important indication of the reduction in ghrelin gene expression associated with the suppression of intake and malnutrition in animals infected with GINs and a decreased inflammatory response in susceptible lambs (Alba-Hurtado and Muñoz 2012).

\section{PERIPHERAL EOSINOPHILS}

Eosinophils are an important element in the inflammatory response against GINs. The association of eosinophils with helminths shows significant correlations between the susceptibility or resistance to infection and the magnitude of the EOS response, which suggests that eosinophils have a role in resistance to helminth infection (Balic et al 2000, Yacob et al 2009). However, in this study, there were no differences between RES and SUS lambs regardless of the method of segregation, which suggests that the immune system is immature at this age; therefore, this parameter cannot be used for the selection of resistance to GINs in young animals (Preston et al 2014). There was also no relationship between FEC and EOS, probably due to the age of the animals. Similar to other studies (Amarante et al 2009), in this study there was a high Spearman correlation between the age of the lambs and EOS. In both RES and SUS lambs, the correlation was between 0.44 and 0.47 $(P<0.01)$. This indicates the maturation of the animals' immune system over the first 10 months of life, unlike another study that indicates that EOS increased from birth to 5 months of age, associated with a subsequent ability to reduce parasite fecundity (Greer and Hamie 2016).

\section{IMMUNOGLOBULIN A}

Secretory $\operatorname{IgA}$ is the main immunoglobulin secreted actively through the epithelium of the mucosa of the 
abomasum (Macpherson et al 2008). IgA response is associated with protective immunity to nematode infections in sheep. However, in our study the low association between the IgA level and the FEC at the beginning was due to the IgA level being dependent on age: after 6 months the FEC fluctuations were related to environmental conditions. For this reason, from July to October (characterised by high humidity), there was an increased FEC, but the IgA levels were relatively low in growing lambs.

The low immunological response to GINs in the young sheep in this study has also been reported in other studies and has been attributed to the low proportion of $\mathrm{CD} 4+$ and CD8+ lymphocytes in young sheep compared to adults. Salivary IgA levels in grazing lambs, determined with a larval antigen (CarLA), indicated that the development of immunity occurs in most animals after 6 months of age (Shaw et al 2013). Also, Smith et al (1985) reported that 4-month-old lambs had a lower response in terms of IgA levels than their 10-month-old counterparts after a challenge with GINs. The negative correlation between IgA levels and infection parameters such as FEC and the number of adult nematodes (Beraldi et al 2008) suggests that it can be used as a marker for resistance selection (Shaw et al 2013). However, in the present study, IgA showed no differences between RES and SUS in all samples. The differences occurred only as a result of age.

Female Pelibuey lambs show high variability in their FEC. The two evaluated methods of segregation allow for the identification of susceptible lambs to a similar extent, but a large number of lambs showed a high degree of infection resistance, as was detected by the M3SE method of segregation, while the method of segregation by QUM selected only $25 \%$ of resistant ewe lambs; for this reason the QUM resulted in low sensitivity and low accuracy. The high PCV and high TPP in resistant Pelibuey lambs can be considered in the phenotypic selection of individuals resistant to GIN, particularly to infections with the hematophagous $H$. contortus. It can also be concluded that the eosinophil count reveals the immaturity of the immune system of 6-month-old in primo-infected lambs and is not an important element in the selection of resistant animals of this age.

\section{ACKNOWLEDGEMENTS}

The study was funded by the programme to support the strengthening of academic bodies PRODEP-DSA/103.5/15/14473. Alvar Cruz Tamayo is a student of Productivity Genetic Resources of Postgraduate College (RGP-COLPOS) and was supported by a doctoral fellowship from the PRODEP-DSA/103.5/16/5957 UNACAM-118.

\section{REFERENCES}

Alba-Hurtado F, Muñoz-Guzmán MA. 2012. Immune responses associated with resistance to haemonchosis in sheep. BioMed Res Intern 2013, article ID 162158.
Amarante AFTD, Susin I, Rocha RA, Silva MB, Mendes CQ, et al. 2009. Resistance of Santa Ines and crossbred ewes to naturally acquired gastrointestinal nematode infections. Vet Parasitol 165, 273-280.

Balic A, Bowles VM, Meeusen EN. 2000. The immunobiology of gastrointestinal nematode infections in ruminants. Adv Parasitol $45,181-241$

Bentounsi B, Meradi S, Cabaret J. 2012. Towards finding effective indicators (diarrhoea and anaemia scores and weight gains) for the implementation of targeted selective treatment against the gastro-intestinal nematodes in lambs in a steppic environment. Vet Parasitol 187, 275-279.

Beraldi D, Craig BH, Bishop SC, Hopkins J, Pemberton JM. 2008. Phenotypic analysis of host-parasite interactions in lambs infected with Teladorsagia circumcincta. Int J Parasitol 38, 1567-1577.

Bishop S. 2012. A consideration of resistance and tolerance for ruminant nematode infections. Frontiers in Genetics 3, 168.

Byers SR, Kramer JW. 2010. Normal hematology of sheep and goats. In: Weiss DJ, KJ Wardrop (eds). Schalm's veterinary hematology. $6^{\text {th }}$ ed. Wiley-Blackwell, Ames, USA, Pp 836-842.

Cloete SWP, Olivier JJ, Du Toit E, Dreyer FH. 2007. Genetic analysis of faecal worm egg count in South African Merinos under natural challenge. South African J Animal Sci 37, 237-247.

Cringoli G, Rinaldi L, Veneziano V, Capelli G, Scala A. 2004. The influence of flotation solution, sample dilution and the choice of the McMaster technique in estimating the faecal egg count of gastrointestinal strongyles and Dicrocoelium dentriticum in sheep. Vet Parasitol 123, 121-131.

Dawkins HJS, Windon RG, Eagleson GK. 1989. Eosinophil responses in sheep selected for high and low responsiveness to Trichostrongylus colubriformis. Intern J Parasitol 19, 199-205.

Emery DL, Hunt PW, Le Jambre LF. 2016. Haemonchus contortus: the then and now, and where to from here? Intern J Parasitol 46, 755-769.

Fakae BB, Musongong GA, Chiejina SN, Behnke JM, Ngongeh LA, et al. 2004. Variability in the resistance of the Nigerian West African Dwarf goat to abbreviated escalating trickle and challenge infections with Haemonchus contortus. Vet Parasitol 122, 51-65.

Gauly M, Erhardt G. 2001. Genetic resistance to gastrointestinal nematode parasites in Rhön sheep following natural infection. Vet Parasitol 102, 253-259.

González-Garduño R, Torres-Acosta JFJ, Chay-Canul AJ. 2014. Susceptibility of hair sheep ewes to nematode parasitism during pregnancy and lactation in a selective anthelmintic treatment scheme under tropical conditions. Res Vet Sci 96, 487-492.

González-Garduño R, López-Arellano ME, Conde-Felipe MM, Mendoza-de Gives P, Aguilar-Marcelino L, et al. 2017. Immune and haematological parameters of Blackbelly ewes infected with gastrointestinal nematodes. Rev Colomb Cienc Pecu 30, 219-230.

Greer AW, Hamie JC. 2016. Relative maturity and the development of immunity to gastrointestinal nematodes in sheep: an overlooked paradigm? Parasite Immunol 38, 263-272.

Landis JR, Koch GG. 1977. The measurement of observer agreement for categorical data. Biometrics, 33,159-174.

Macpherson AJ, McCoy KD, Johansen FE, Brandtzaeg P. 2008. The immune geography of IgA induction and function. Mucosal Immunol 1, 11 .

Mavrot F, Hertzberg H, Torgerson P. 2015. Effect of gastro-intestinal nematode infection on sheep performance: a systematic review and meta-analysis. Parasites \& Vectors 8, 557-568.

McMahon C, McCoy M, Ellison SE, Barley JP, Edgar HWJ, et al. 2013. Anthelmintic resistance in Northern Ireland (III): Uptake of 'SCOPS' (Sustainable Control of Parasites in Sheep) recommendations by sheep farmers. Vet Parasitol 193, 179-184.

McRae KM, McEwan JC, Dodds KG, Gemmell NJ. 2014. Signatures of selection in sheep bred for resistance or susceptibility to gastrointestinal nematodes. BMC genomics 15, 637.

McRae KM, Stear MJ, Good B, Keane OM. 2015. The host immune response to gastrointestinal nematode infection in sheep. Parasite Immunol 37, 605-613. 
Morris CA, Vlassoff A, Bisset SA, Baker RL, Watson TG, et al. 2000 Continued selection of Romney sheep for resistance or susceptibility to nematode infection: estimates of direct and correlated responses. Animal Sci 70, 17-27.

Morris CA, Wheeler M, Watson TG, Hosking BC, Leathwick DM. 2005. Direct and correlated responses to selection for high or low faecal nematode egg count in Perendale sheep. New Zealand J Agricul Res 48, 1-10.

Morteo-Gómez R, González-Garduño R, Torres-Hernández G, NuncioOchoa G, Becerril-Pérez C, et al. 2004. Efecto de la variación fenotípica en la resistencia de corderos Pelibuey a la infestación con nematodos gastrointestinales. Agrociencia 38, 395-404.

Palomo-Couoh JG, Aguilar-Caballero AJ, Torres-Acosta JF, Magaña-Monforte JG. 2016. Evaluation of different models to segregate Pelibuey and Katahdin ewes into resistant or susceptible to gastrointestinal nematodes. Trop Animal Health Prod 48, 1517-1524.

Peña-Espinoza M, Thamsborg SM, Desrues O, Hansen TV, Enemark HL. 2016. Anthelmintic effects of forage chicory (Cichorium intybus) against gastrointestinal nematode parasites in experimentally infected cattle. Parasitology 143, 1279-1293.

Preston SJM, Sandeman M, González J, Piedrafita D. 2014. Current status for gastrointestinal nematode diagnosis in small ruminants: where are we and where are we going? J Immunol Res 1-12.

Rose H, Rinaldi L, Bosco A, Mavrot F, De Waal T, et al. 2015. Widespread anthelmintic resistance in European farmed ruminants: a systematic review. Vet Record 176, 546-546.

SAS, Statistical Analysis System. 2004. SAS Version 9.2. SAS Institute Inc., Cary, NC, USA.
Shaw RJ, Morris CA, Wheeler M. 2013. Genetic and phenotypic relationships between carbohydrate larval antigen (CarLA) IgA, parasite resistance and productivity in serial samples taken from lambs after weaning. Intern J Parasitol 43, 661-667.

Smith WD, Jackson F, Jackson E, Williams J. 1985. Age immunity to Ostertagia circumcincta: comparison of the local immune responses of 41/2 and 10-month-old lambs. J Comparative Pathol 95, 235-245.

Stear MJ, Fitton L, Innocent GT, Murphy L, Rennie K, et al. 2007. The dynamic influence of genetic variation on the susceptibility of sheep to gastrointestinal nematode infection. J Roy Soc Interface 4, 767-776.

Sweeney T, Hanrahan JP, Ryan MT, Good B. 2016. Immunogenomics of gastrointestinal nematode infection in ruminants-breeding for resistance to produce food sustainably and safely. Parasite Immunol 38, 569-586.

van Wyk JA, Mayhew E. 2013. Morphological identification of parasitic nematode infective larvae of small ruminants and cattle: a practical lab guide. The Onderstepoort J Vet Res 80, 539.

Yacob HT, Mistre C, Adem AH, Basu AK. 2009. Parasitological and clinical responses of lambs experimentally infected with Haemonchus contortus (L3) with and without ivermectin treatment. Vet Parasitol 166, 119-123.

Zaragoza-Vera CV, Aguilar-Caballero AJ, González-Garduño R, ArjonaJiménez G, Zaragoza-Vera M, et al. 2019. Variation in phenotypic resistance to gastrointestinal nematodes in hair sheep in the humid tropics of Mexico. Parasitol Res 118, 567-573.

Zaros LG, Neves MRM, Benvenuti CL, Navarro AMC, Sider LH, et al. 2014. Response of resistant and susceptible Brazilian Somalis crossbreed sheep naturally infected by Haemonchus contortus. Parasitol Res 113, 1155-1161. 